\title{
David Charles Morton mbBS(Hons), FRCOG, FRANZCOG, DDU
}

DAVID MORTON was born in Wauchope, New South Wales, on 9 May 1929, the son of a teacher. He achieved a maximum pass in the Leaving Certificate from Sydney Boys High School and commenced medicine at the University of Sydney in 1946. His older brother Max and sister Marion were both prosectors in anatomy there. David's first year marks made him the family's third prosector - a unique achievement. During his obstetric term at the Royal Hospital for Women in Randwick, he met his future wife Dorothy Ironside.

David graduated with honours in 1952, married in 1953, completed 3 years' residency at Royal Newcastle Hospital and ran a very successful general practice at Port Macquarie until 1964. He then specialised in obstetrics and gynaecology, achieving membership in the Royal College of Obstetricians and Gynaecologists (RCOG) in 1966 after posts at Royal Hobart Hospital and in the United Kingdom.

David began his specialist referral practice at Gosford in 1968 - the first fully trained obstetrician on the Central Coast of NSW. He attained Fellowship of the RCOG in 1977 and became a Foundation Fellow of the Royal Australian and New Zealand College of Obstetricians and Gynaecologists in 1979. He was actively involved with College affairs, the Newcastle Obstetric and
Gynaecological Society, and the Board of the Hunter Postgraduate Medical Institute. David and Dorothy were active members of the Australian Gynaecological Travelling Society.

After acquiring a Diploma in Diagnostic Ultrasound, David and Dorothy (a qualified ultrasound radiographer), with the late Dr Malcolm Catt, developed an ultrasound facility serving the Central Coast until David retired in 1996.

After the unexpected death of Dorothy in 2005, David met Robyn Ryan, who became much loved by the wider Morton family and was a wonderful support to David.

David was a talented painter and woodworker, and he applied these skills to make presents for his grandchildren. He coped with his final illness of pancreatic cancer in his typical fashion - remaining positive and inspiring to the end, and dying peacefully at home on 6 March 2012. David was extremely modest about his many achievements and was very family-oriented. He is survived by his three children John (an orthopaedic surgeon), Robert (a general practitioner) and Janette (a physiotherapist), nine grandchildren and one great grandchild; his granddaughter Susan graduated in medicine earlier this year. We were all privileged to have been part of his life.

Alan D Hewson doi: 10.5694/mjal2.10536 